\title{
Escaping Prophets in Zomia: The Sect of Ziona
}

\author{
Vanlalpeka \\ Department of History, Academy of Integrated Christian Studies, Senate of Serampore College, Mizoram, India
}

Copyright $(2019$ by authors, all rights reserved. Authors agree that this article remains permanently open access under the terms of the Creative Commons Attribution License 4.0 International License

\begin{abstract}
This paper discusses about the biggest family in the world, the family of Pu Ziona, which has unique and peculiar stories to tell. The religious community led by the different leaders of the sect has fascinating narratives exotic manifestations, polygamous feature, isolation from mainline society, communal life, and exceptional adaptability for economic sustenance. Presently, the nephew of the founding father, $\mathrm{Pu}$ Ziona inherited leadership of the community from his uncle and has as many as 39 wives, women of different dispositions with diverse family backgrounds. The community of Ziona also known as Lalpa Kohhran Thar (New Church of the Lord) or Chhuanthar Kohhran (Church of New Generation) has not simply survived in a context in which denominational churches have forced most new religious movements to fizzle out after a couple of decades or so; the Ziona's family has been flourishing. Looking at the close resemblance of the community with that of the Church of Jesus Christ of Latter Day Saints, Lalsawma called the movement The Mormons of Mizoram, also comparable with The Family in America. Like other new religious movements in the state, Vanlalchhuanawma observes that there is an "anomalistic" trait that protests against the orthodoxy of mainline churches. The community is dominated by a number of mythical features - the unchallenged status of the founding fathers, the uniqueness of the members and their unique destiny, etc. Revelation is something that is continual and keeps on going, and in this sense they challenge the unique revelation found in the Bible. In the same line, the community's dream has been characterized by millenarianism that is distinctly utopian. They expect the coming of a golden age in which the church's members will be redeemed from imminent disaster and will be given special privileges in a post-apocalyptic period. Oftentimes, they considered themselves the new Israel, the new chosen nation/family.
\end{abstract}

Keywords Zomia, Sect of Ziona, Sect in Mizoram, Christian Polygamy

\section{Introduction}

Ranked by the Guinness Book of World Records as the biggest family in the world, the family of Ziona has unique and peculiar stories to tell. The religious community led by him in northern parts of Mizoram, in the northeast region of India, has fascinating narratives - the by-product of Christian revival movements, unchecked marital relationship, and isolation from the mainline society, often interpreted as a form of resistance against the church and the society. On the other hand, the communal life and exceptionally economic sufficiency seems to have been grounded in the socio-economic set up of the Mizo. Presently, the nephew of the founding father, $\mathrm{Pu}$ Ziona inherited the leadership of the community and has as many as 39 wives, who are women of different disposition with diverse family backgrounds. The community of Ziona or Lalpa Kohhran Thar (New Church of the Lord) or Chhuan thar Kohhran (Church of New Generation) has not simply survived a context in which denominational churches are extremely powerful that most new religious movements fizzled out after a couple of decades or so, they have flourished by devising the scheme to escape from incorporation into the dominant society that is highly been characterized by Christian faith. They have grown from being a small community to becoming 2500 members today [1].

After the Anglo-Burmese War (1824-1826), treaty of Yandaboo was signed in 1826 that officially authorized the British to extend their sovereignty over the hilly regions of Northeast India, including Mizoram. The people continue to be insulated from the assimilative sanskritization of the mainline Hindu religion. The Mizo continue to live under their traditional chieftainship and maintains their unique identity and tribal practices. [2] With the intrusions of British power and Christian Mission, the world of the people was turned 'upside down' in almost every sphere of their lives [3]. However, the different traditional communitarian traits of the Mizo people also make their appearance again in the gradual unfolding of her history.

Strictly situating the history of the Mizos as one of the tribal groups of Northeast India tends to label them as an alien community with linguistic foreignness and unique socio-cultural ethnicity. There is no denying the fact that the community has come under the political administration 
of the Indian Union since the last part of the nineteenth century; however, the Mizo's ethnic roots and cultural identity have closer connections to the other Southeast Asians, and Mongoloids than with the Sanskritic Indians. This paper will deal with the sect of Ziona in Mizoram and their unique experiences of survival by locating the people as part of the Mongoloid community in Southeast Asia and drawing a parallel line with that of the other Southeast Asian communities.

\section{Zomia: Zone of Resistance}

A non-Sanskritic name 'Zomia', an anglicized version of Zomi [4], denotes non-state spaces in Southeast Asia that embraces the highlands of Asia - starting from the western Himalayan range to the Southeast Asian highlands through the Tibetan Plateau and continuing to include the other neigbouring highland regions. A land best remarked as peripheral spaces to kingdoms and states, hidden and overlapping identities with little or no affiliation to any state and power [5], Willem Van Schendel proposed the term Zomia in 2002 to "challenge the fixed boundaries of classical 'Area Studies"” [6]. According to Jean Michaud, "Zomia is an area marked by a sparse population, historical isolation, political domination by powerful surrounding states, marginality of all kinds, and huge linguistic and religious diversity." [7] In spite of the diverse socio-political experiences, the people have sets of common ideas, parallel social systems and peculiar agrarian lives. Michaud also writes:

They include language affinities (for example, Tibeto-Burman languages), religious commonalities (for example, community religions and, among the universalistic religions, Buddhism and Christianity), cultural traits (for example, kinship systems, ethnic scatter zones), ancient trade networks, and ecological conditions (for example, mountain agriculture). [8]

Considering the spaces of Southeast Asia, Willem Van Schendel tries to find how "area knowledge" is classified along the line of 'heartlands' and 'border-lands' by spatialising different social concepts and theories. Southeast Asia was often known as a geographical expression with clear cut boundaries and geographical demarcations, scholars on the subject employed the human bonds and common identity that make the area as anit. The borderlands often remained undisputed as they are often forgotten and overlooked. [9] The fluidity experienced in the Zomia borderland and socio-cultural margins that often overlapped one over another creates a milieu of unlawful deals evading most state regulations. Beyond the official records of both spaces, there was a thriving arm trade, illegal drugs deal and unchecked cross-border activities with little supervision [10]. Population away from state spaces and state making developments, one of the chief traits is undoubtedly resistance. In fact, the land still hosted different insurgents and turned out to be a 'safe haven' for different factional groups that resist state power even in the twenty first century.

James C. Scott observed and concluded that the people with their so called 'primitive' cultural traits are to be considered as having adapted deliberately to evade state capture and state formation.[11] So as to escape from the state control, they resorted to different schemes that would protect them and yet help them to formulate their own communities. Such adaptation to escape being governed is seen in their economic setup, social life, political system, and also religious life as different prophets make their appearances from time to time.

Religious upheavals led by some 'holy men' also have been considered as one of the several techniques to escape the state-making machinery. D. L. Brayton who served as a missionary among the Karen expressed that one of the important ethnic identities of the people was the rise of different prophets among them. [12] The conversion of the people to a particular religious conviction never hindered them from their devotion to such millennial prophets empowered with charisma, healing power, prophetic visions and wonder-working power. The people also expected a sudden reversal of destiny, a situation of a world turned upside down in which fortune would go in favor of them. Generally, people in the hills are receptive to prophetic works, especially those that would change their destiny for good. The different religious uprisings are often considered resistant movements, or denials of assimilation into the mainline society, an attempt to break away from state-sponsored religion. [13] It can be deducted that such resistance does not always culminate into violent forms but sometimes symbolical trends.

Leaders of such movements provided a matrix in which the members would orient themselves to the new settings. [14] They have their own 'millennial cosmology' which was not associated with the lowland states or the mainline society from which maintaining some distance is a necessity. [15] The amalgamation of their pre-Christian worldview with that of Christian faith sets Christianity as the fulfillment of their former traditions. For instance, one prophet among the Lahu tribe prophesied Christianity as the culmination of the pre- Christian millennial cosmology, bringing many countrymen into the fold of the church, but he had to be exiled as he took many wives, unacceptable in the eyes of the church. [16] Zones in Zomia are characterized as lands of refuge for different resistance groups.

\section{3. "Lalpa Kohhran Thar" (The New Church of the Lord)}

The different tribal movements of India have been analyzed by a number of scholars like Jay, Stephen Fuchs, 
K.S. Singh, I.P. Desai, Bhadra and others who have given special attention to the religious/revivalist nature. The movement, as seen by Stephen Fuchs, is Messianic and Millennial with a leader who assumed the role of a prophet or a seer. The leaders are individuals gifted with abilities to take the role of a Savior, or the community themselves insisted them to lead them when they faced socio-economic and political turmoil. Accordingly, Fuchs articulates that the success of such developments depended on the persona and skills of the leader, while the system that characterized the origin and feature of the movement was not the sole deciding factor, [17] the same analysis perfectly suits the community of Ziona.

In 1939, a group of revivalists under the leadership of Khuangtuaha experienced excommunication from the church for the "delinquent nature" of Khuangtuaha, a man who had mystical and extreme exotic behaviors. He was imprisoned twice and his later movement was restricted by the then colonial British government. They compelled him to settle in the village of Hmawngkawn, and he later moved to Baktawng. People from different villages who were drawn to him by his magnetic personality visited and gradually settled with him in the midst of different degrees of harassment. They gradually established their own colony in the outskirts of the village of Baktawng, later known as Tlangnuam.

The community understood their church as Lalpa Kohhran Thar (New Church of the Lord) or Chhuan Thar Kohhran (Church of the New Generation). The community is also known by the leaders of different eras - Khuahtuaha (1936- 1955), Chana (1955 - 1997) and Ziona (1997present). The community first known as "Sect of Khuangtuaha," was later known as "Sect of Chana", and is presently known as "Sect of Ziona". Members who joined the movement were initially revivalists whose behaviour the church could not condone. It was the period in which the Mizo community was in transition from tradition to modernity. The denominational churches were adversely affected by their stance on different traditional elements, among which rice beer and its consumption resulted in a number of Christians leaving the church. Circumstance compelled it to formulate itself as a religious community of its own and it started to de-emphasize the role of clerics, the organizational set-up of a denominational church, and gradually all types of orthodoxy that the church represented.

\section{Exploring the Different Hotupas (Leaders)}

The leaders of the community are known as hotupa, that simply means "leader", which is not strictly a religious or spiritual name, but instead it has a social implication. However, most of the members called him " $K a p a$ " which simply mean 'father', by which the leader performed a fatherly role towards members of the social and religious community. In the same line, the whole community revolves around the uncontested leader (hotupa) as the religious and social patriarch. Evolving from a small settlement into a well established city-state like village, the leader, especially during the time of Pu Ziona, acts as the social head as well as the religious leader of the community.

The three eras of different leaders is given in the following way below:

1. Khuangtuaha (1936-1955): He was born in 1891 and grew up at Sialsuk and Hmawngkawn villages. He was known to be handsome and charming, physically well-built and strong, which earned him the admiration of the villagers of his time. He was one of the few Mizos who helped the British in their war against the Abors in Arunachal Pradesh and he also went to France during World War I as part of the Labour Corp. He was known for his magnetic personality and he was also described as a "Casanova" of the village. [18] However, the spiritual revival during 1935 became a life changing experience for him. During such stirrings, revivalists often openly championed spiritual freedom in Christ that extends to one's freedom from carnal desires. Sometimes, spiritual freedom is so exaggerated that it is considered still Christian to have an illegitimate child. [19]

In 1942, Khuangtuaha was excommunicated by the church for having an illegitimate child. Along with him, the most prominent village elder and eight Sunday School teachers were excommunicated which must have been a great blow to the church. He was also afterwards casted out by the village authorities of Hmangkawn. When he went to Lungrang village, the chief's daughter fell in love with him and eventually he had another illegitimate child through her. When he was expelled from Lungrang, he moved to Lamchhip. His presence in Lamchhip was a serious threat to the church as many church members were drawn to him which, in turn, often necessitated the cancellation of different worship services.

His vision of three prominent stars in 1937 convinced him of his unchallenged religious status that exalted him to be an unrivalled leader. [20] The popularity of Khuangtuaha could not be tempered by excommunication or expulsion. In 1942, he was arrested and placed under custody in Aizawl jail, but he was released on bond of promise to move out of Mizoram at the behest of the Superintendent of the Lushai Hills. He was arrested again and imprisoned for nine months in 1943. [21] Acknowledging his service during the Wars, he was released again and he was allowed to return to Hmawngkawn on the condition that he would not 
travel anywhere in Mizoram. Keeping his promise, he never journeyed again. Instead, his admirers would flock around him and gave him whatever he needed. He then formed his own community. [22] The community went "underground" from society for a couple of years, as the ethical standard of the modern Christian society could not tolerate them. He introduced inrul (having an affair) between revivalists of opposite sex. Partly because of such practices, from the perspective of the church, the sect of Khuangtuaha is considered as a sexually perverted community. He also heavily indulged himself in drinking beer which he justified as a means of warding off the grudge and rivalry of the church and the state so that he would be seen simply as another vagabond of the village. By the time Khuangtuaha died on $30^{\text {th }}$ March 1955 , he was already a demi-god for members of his community. His role in the community was taken up by his younger brother named Chana.

2. Chana (1955 - 1997): Challianchana, popularly known as Chana, was born in 1944. He was the younger brother of Khuangtuaha. He was far more educated than his elder brother Khuangtuaha. He passed middle school in 1928, an educational standard considered fairly good in those years since the region the first High School was built only in 1944. Soon after the death of Khuangtuaha, he took up responsibility of the leadership. The community became more institutionalized by discarding many of the immoral behaviors. The practice of drinking beer common during the time of Khuangtuaha subsided. However, the deprecatory connotations associated with the new church did not go away altogether. Pu Chana was accused of keeping a very obscene room called "Mawng en Pindan", a room in which buttocks are examined. The historical reliability of the accusation is hard to determine. However, it is noticeable that in the opinion of the masses, the community was associated with immoral accusations and abomination.

As a great upheaval in the form of the Mizo uprising against the Indian Union erupted in 1966, the Indian government retaliated harshly by employing several stern measures. One such measure is called the 'grouping of villages' in the name of "Protected and Progressive Villages."[23] In 1967, the village of Hmawngkawn came under Baktawng and they are compelled to settle in Baktawng. [24] The socio-geographical changes broke their isolation as well as their segregation. The church also experienced increase in membership in the 1980s as many admirers migrated to the village due to fear of an imminent earthquake. During those times, the strength of the community was around 103 houses with 700 members.

As the state experienced a number of political changes, the community also tended to be more open to such changes in the form of political participation and other changes. The church also witnessed more institutionalized set-ups. The establishment of Israel Thar Thalai Pawl, a new youth organization in 1971, bore the signature of the denominational church among which the first youth department Thalai Kristian Pawl (Christian Youth Department of the Baptist tradition) was started as early as 1951 .

3. Ziona (born. 1944): The third leader Zionnghaka seems to be the most powerful and significant, as the community witnessed a number of upheavals and changes. According to oral tradition, he was predestined to be the leader of the community since his childhood. As a community initially started as a rebellion against formalism, orthodoxy and proper structure of the church began to organize itself into a more formal and systematic institution. As the community is also doing economically well, it is possible to reinforce the institutional set-up of the church as well as the communitarian bond.

The chief uniqueness of Ziona from his predecessors is the degree of polygamous relationships within the family. To date, it is recorded that he has as many as 39 wives living under the same roof; some have a room of their own and some share their room with other wives. The first wife of Pu Ziona, Zathiangi, manages the household matters and cases of disputes between the different wives are extremely rare. The community is well regulated with supportive mates/co-wives and it de-emphasizes competition and stress in relationships.

Ziona married his first wife Zathiangi in 1959 and they lived as a normal couples and he married his second wife after Zathiangi bore two children about seven years later. There is no denying the fact that the marriage is considered by the members as something that is divinely ordained, and Zathiangi sincerely admitted that at first it was not easy. However, the unique familial relationship is considered to be divinely ordained. Eligible brides actually pleaded to marry him and sometimes the parents of the bride encouraged the matrimonial tie. There were instances in which he tied the knot with a number of brides together at a time. The brides of such cases are exclusively from their own community, known as Chhuanthar Church (Church of New Generation). It is said that Ziona is ever ready and open for more matrimonial alliances. 


\section{Belief System}

Looking at the close resemblance of the community with that of the Church of Jesus Christ of Latter Day Saints, Lalsawma called the movement The Mormons of Mizoram, [25] also comparable with The Family in America. [26] Like the other new religious movements of the state, Vanlalchhuanawma observes that there is an "anomalistic" trait that protests against the orthodoxy of the mainline churches. [27] Mangkhosat Kipgen remarked on the highly subjective understanding [28] of Christian faith and revelations. He also observed that as the Christian faith was indigenizing the life of the people, the members of the sect failed to distinguished elements that contradict with the core meaning of Christian faith. Therefore, like most of the new religious movements experienced in the region, they are subjective and free from tradition and the orthodoxy of the church.[29] Therefore, their belief system is hard to label within a fixed tradition or under a rigid theological traditions. Being a persecuted community that is despised and harassed physically and mentally, it easily observed that adjustment and reorientation in their belief system is a common phenomenon. However, some of their major beliefs could be summarized as follows.

\section{Millenarianism}

The community is dominated by a number of mythical features - the unchallenged status of the founding fathers, the uniqueness of the members and their unique destiny, etc. Revelation is something that is continual and keeps on going, and in that sense they challenged the unique revelation found even in the Bible. Some of the frequently quoted Bible texts are I Thessalonians 4:17, Revelation $11: 4 ; 20: 4 ; 14: 6$. [30] As the Bible hardly deals with the issue of "Ram Thar" (New Land or New Kingdom), the foundation of their church, it is considered insufficient for them. [31] The uniqueness of their belief system is marked by outlining the salvation of the body not just the spirit. [32] In the same line, the community's dream has been characterized by a millenarianism that is distinctly utopian. There is expected to be a golden age in which the church's members will be redeemed from imminent disaster and they would be given special privileges.

\section{Indigenous Orientation}

The Chhuanthar Kohhran has volumes of literature to train and orient their members through Sunday school, with the hymns and responsive readings composed by the leaders. For a couple of decades, they developed their songs after the tune of TlanglamZai, which is a Mizo three line song that the church bitterly opposed as animist and unchristian. They also incorporated Mizo dancing called Chheih Lam. They compiled a song book of their own entitled Lalpa Kohhran Thar Hlabu, meaning "Song Book of the New Church of the Lord".

All the songs highlight how efficient their leaders are in fueling the hope of the adherents in spite of their hardships and different life struggles. They are provoked and emotionally moved and encouraged to stand. Being a community that witnessed recurring harassment, they retained their status and destiny as the chosen ones; however, the zeal for evangelizing others has never been the dominating agenda of the community.

The members are also taught the so called responsive reading ("Thu Inchhang") that involves articulations that are highly indigenous and rooted in the daily lives of the members. One of such is as follows:

$\begin{array}{lll}\text { Mizo Version } & \text { English Version } \\ \text { Zawhna: } & \text { Hmeichhe duhzawng enge ni? } & \text { What does a woman want? } \\ \text { Chhanna: } & \text { Chakai. } & \text { A Crab } \\ \text { Zawhna: } & \text { Mipaduh zawng engnge ni? } & \text { What does a man want? } \\ \text { Chhanna: } & \text { Uituaisa. } & \text { Tender Dog Meat } \\ \text { Zawhna: } & \text { Lalpaduhzawng engnge ni? } & \text { What does the Lord want? } \\ \text { Chhanna: } & \text { Hun Tharhawn. } & \text { To open a new era }\end{array}$

Another responsive reading goes in the following ways.

Mizo

Zawhna: Pathianin vanah engnge min pek ang?

Chhanna: Kamiste, chithlumte min pe ang

English

Question: What will God give us in heaven?

Answer: God will give us shirts and candy in heaven.

The diverse literatures bear the signature of their rivalry with the denominational church and also the Christian missionaries. Dominating traits of the community exhibit the anti-legalistic, anti-orthodox, indigenous, exotic, and exclusive stands which truly highlight their identity. The often democratic impulse of Mizo revival also promotes liberty and freedom. It is well polished with language that is rooted in the worldview and daily experiences of the tribal people as they are. Of all such articulations, the most significant must be the sexually vulgar words and sentences that triggered their thoughts and hooked up the attention of the members automatically. 


\section{Cultic Elements}

Lalpa Kohhran Thar is a community that was cultic in its approach right from inception. It is not so much about a particular doctrine or tradition that is the central core of the church; it is rather a church which strictly rests on the leaders. It is centralized in its approach and its dealings with its members. As the movement evolved, it witnessed further departures from some of the basic Christian beliefs and traditions. The following lines seem to highlight how they understand their leaders:

\section{Mizo Version}

Cherra leh BD a chhing ngei dawn,

Vanhnuai sel vel Mission runpuia hnawng hnu;

Zion tlang champion a chang ngei dawn.

The community has also had the so called "In Pui" (Central house or main house) since 1956. It is the house in which the leader of the cult lives with his wives. Today, it is a great four storied building 140 feet long, and 98 feet wide, a four storied building. It serves as the lifeline for any kind of communication, disciplinary matter, vision, or direction of the church. It resembles the Zawlbuk of the Mizo traditional village system that served as the foundation of their social relationship. The church set up soon developed into a highly centralized structure in which selected religious leaders stand above the laity, with the leader at the top of the pinnacle.

It is hard to understand their doctrine of Trinity in the sense that God as the Father is worshipped. The intermediary role of Jesus Christ is not well articulated. The symbol of the community is a star that bears close resemblance with the Davidic Star rather than a cross. The object of worship is claimed as God the Father, and prayers are asked in the name of God himself, but the name of Christ is hardly mentioned. However, by 1960 some members of the church during those times opined that they began to obliterate the name of Jesus Christ. Many faithful adherents left the church saying that the leader was exalted above Christian deities. [33]

In the same line, the Bible is not the foundation of their religious life even though most households keep a copy or so. In their worship services, they do not bring their Bible with them, and sharing and preaching is mainly based on their own personal reflections without any reference to Scripture. However, assessing the community with this evidence alone as a deviation from the mainline church could also be biased as well because of the fact that the first adherents were almost illiterate. [34] Henceforth, either a denial of the Bible or practical necessity compelled them to be a community that has little to do with the Bible.

The community does not celebrate Christian festivals such as Palm Sunday, Good Friday and Easter; instead, they celebrate the birthday of their founding fathers and family events. Christmas is celebrated sometimes just for namesake. This is justified as a means to escape the heavy celebrations that is often so involved. Instead, the community's celebration revolves around the events of the three founding fathers- Khuangtuaha, his son $(\mathrm{Pu}$ Challianchana or Chana) and grandson (Pu Zionnghaka or Ziona). Of all the different celebrations, the birthday of $\mathrm{Pu}$
Ziona is the most significant and most important for the community. [35]

\section{Practice and Tradition}

Initially the sect of Ziona was developed out of the matrix of rebellion against the organized church that is highly unorthodox in its approach and dealings. The movement is characterized by a separatist inclination and missionary zeal that is only symbolic by nature since the tradition exhibits territorial elements in the belief system. Lack of any formal institutional religious set up compelled them to become more and more intuitive, moving further away from the orthodoxy of the church. The mediating role of the church as often traditionally understood is taken on by their leaders who are also believed to have "hidden wisdom" based on extra sensory discernment. Sometimes the indoctrination of the members within their own community disorients them from the normal social system.

\section{Organizational Set Up}

Before the community ceded from the church, admirers were drawn naturally to the leaders. Development of the community is seen in relation to the formalization and institutionalization of the whole system. The leaders are known by different titles such as "Maicham", which means alter, "Zawlnei Thuhruk" (Hidden Prophet), "Tehtu" (One who Measure), "Thu Dik Thlen Dikna", which means the Truth Chapter and he is also compared to Moses. The leaders are endowed with the capacity to prophesy and see into the future. [36]

The church of the community has its own Upa (Church Elder), a system very similar to that of the denominational churches. The role of the priests is very significant as they act as the moral guardians of the members through their visions. The community follows a more and more organized formation and sometimes even imitate military organizations as one of the groups is called Chhuanthar Military; they are dressed in blue uniforms and often command the whole gathering during their grand festivals. The dancing during worship services depend on the mood of the dancers/members and the drummers. The leader himself notified the exact number of dancers for a particular session. 


\section{Communal Life}

Of all the different family categories proposed, the "communal family" as labelled by Melton bears the most significant resemblance to reality. It is not something unique and novel in the history of Christianity. It is rooted in the biblical teachings of Acts of the Apostles (4: 32-35); however, the communal life of Khuangtuaha seems to have been propelled by economic and social necessity rather than solely the biblical teachings. [37] The communal life is well-rooted in strong leadership, strong social control and behaviour, economic self-sufficiency mainly based on sharing, and isolation from mainstream society. They maintain complete isolation from the society during times of death and funerals. This societal relationship negates the very foundation of Mizo traditional society as death and funerals distinctively mark the Mizo society, [38] as also a sharing society.

The communal bond of the church seems to be concerned with social reality as observed by Emile Durkheim, for whom social life is naturally religious and rituals are the celebration of social life rather than strictly the revelation of the supernatural beings. [39] In that sense, religion is able to reinforce a sense of belonging in the minds of all members of the society. This opinion became more relevant in the gradual development of the community that witnessed the role of leaders in social and ethical lives of the members. In the same way, the building for religious gathering is known as "Chhuanthar Run" (House of New Generation), here "house" simply means social space. On the other hand, the stadium in which they gathered together to play football is considered as a sacred space.

\section{Sex and Polygamous Structure}

The most infamous gossip about the church is its permissive share on sexual relationships. Subscribing Christian liberty in the spirit and stretched to suit their own interest, some members seem to define their liberty to include sexual intercourse outside formal marriage. Some claimed an illegitimate child as the child of the Holy Spirit. They would not entertain anyone who criticized such relationships and rather counter attack such people and the orthodoxy of the church itself. One of the songs goes in the following ways:

\section{Mizo Version}

Di ngaih a thiang lo tifosuh $u$,

Van lalPathian in fuihpawrhzo dawn e;

In railehsi thin ngawirengru.

\section{English Translation}

Don't tell me it is unchristian to have sex with one's lover,
Lest you provoke the anger of God the Father;

You often have illegitimate children, in return, just keep silent.

The polygamous nature of the community has been one of the remarkable traits from the very beginning. Khuangtuaha had 5 wives, Chana had 7, [40] and Chana's son Zionnghaka or Ziona had 37 wives. The polygamous nature is mainly found in the leadership of the communities that either reinforces or institutionalizes the system and is disgracefully named him like that of a "wine taster". There is an extraordinarily strong emotional bond attached to the leaders, especially by the female members. The polygamous relationship seems not just a relationship between the leader and an illegible bride, but it is also a matter of security and financial stability. A cursory glance over the system lured many observers to classify it as an institutionalized form of sexual freedom.

The polygamous relationship is understood as divinely ordained on the condition that candidature for the marital knots do not always include the most eligible maidens, some of them partially lame, some of them advanced in age or economically poor. If that is the case, the matrimonial alliances could not simply be out of sexual perversion or fulfillment of one's carnal desires. Instead there must have been a higher purpose. As is often the case, a person in need takes refuge under the province of the traditional Mizo chiefs and other prominent leaders. The practice is such that whoever took shelter under his roof would never be either rejected or denied. In the same manner, the leader of the church would never deny any woman interested in him. He would accept them and love them in return. The impartial treatment given to the wives is often the chorus repeated many times by the wives. At the same time, the polygamous structure in turn reinforced the leadership within the group. Above all, it reinforces the centrality of the leadership of the hotupas.

\section{Ethical Codes}

With regard to ethical teachings, the sect also sets its own trend. Unlike many other new religious movements of the past that proclaimed the teachings of self-conquest, it taught fulfillment of oneself - emotionally, mentally, and physically, including the fulfillment of one's sexual desires. None of the ascetic ingredients found in the history of Christianity can be seen in its background. On the other hand, Ziona's community is free from self-destructive behaviour. [41] Probably because it isolated itself from society and its members are well indoctrinated. Concern is also being raised to understand the impact of one's prior socialization, education, and peer and family backgrounds for understanding the entry of members into the community. [42]

The system of brainwashing also known as 'coercive persuasion' or 'thought reform' is being carried out to a very mild and ideological degree. As Saliba observes, the 
"indoctrination techniques serve as a maintenance mechanism that shelters them from the outside world and continuously inculcates the virtues and benefits of their new lifestyles." [43] The Ziona's sect also inculcates the values of their community in pursuing economic stability and socio-political steadiness which was for survival. With each socio-economic improvement of the group, the community gradually experienced improvement in different facets of life. The communal lifestyle has been presented to an outsider as something that is beautiful and unique. It is highly debatable that the communal relationship works against the individual identity, anti-self or anti-family.

\section{Sustainable Approach}

Vanlalchhuanawma remarked that most religious movements in Mizoram did not survive as a powerful force for long due to their incompetent leadership - illiterate and unpolished thought. [44] The community of Ziona, on the other hand, outlived almost all other groups even though their membership is equally illiterate and dominated by unpolished thoughts.

Members of the community are known for their hard work ethic. They are the trend-setters in reviving the traditional utensils, door panels, ventilation frames, tables, beds, cupboards, and rallying and door/window frames. A research conducted by EMOTOME, NDBI, National Institute of Design, Ahmadabad, Gujarat in 2012 highlighted that the locality known as Baktawng, Tlangnuam has as many as 15 wood carpentries. Out of 140 households in the village, $85(=61 \%)$ household units are engaged in this carpentry work. The average annual income of such families from carpentry could be around Rs. 3, 02,368/-[45] which is comparatively good for any remote villages in Mizoram. Carpentry and other crafts enabled them to continue their economic activity without much interaction with the outside. As a semi-closed society it is also possible for them to regulate their own lives without conforming to outside norms. In short, the economic engagement of the people permitted them to live in a fair, stable economy that helped them to retain their uniqueness and stability as a group.

\section{Church and Community of Ziona}

The indigenizing influence was taken seriously by the church, either consciously or unconsciously. The church publication of HarhnaHruaina $\mathrm{Bu}$ (the revival Guide) in 1949 helped Christians to remain faithful to their church's principles. The various local churches were opened to the indigenizing process of the Christian faith. [46]

While there was strained relationship between the two mission churches - the Presbyterians and the Baptists, the Sect of Ziona somehow gets along well with other churches, also expelled by the denominational churches. Thiangzau church maintained a very positive attitude towards the community and they were given a chance to greet the delegates in Thiangzau conferences. When Zakamlova was about to start a new church called the United Pentecostal Church, he invited them three times. The so-called Isua Krista Kohhran (IKK) also invited them to join their church two times. Vanawia, leader of one of the most well-known new religious group in the region also invited them to start one new church. [47] However, they declined all the proposals so as to retain their unique identity.

\section{Conclusions}

Autonomy from the church as well as the state defines the identity of the sect of Ziona and this alienation compelled them to embrace their leaders and seek them as the final authority on most cases. It would not be an exaggeration to state that this is a community that follows an 'escaping prophet' from the mainstream society. The chief uniqueness of the community lies in the polygamous relationship of its leaders while it is often the area which confuses many observers. The richness and diversity of the community lies far beyond the polygamous behavior of their leaders. The polygamous feature was not the core structure of the family in its initial period, but it is more of a recent development.

It is evident that there is an ongoing dialogue between their belief system and socio-cultural reality. Many Mizo cultural elements are preserved and sustained through the religious beliefs and traditions of the community that in turn molded not only the socio-cultural and ecclesial set up of the community but also their belief systems and the traditions. The pride of the Mizo community, sharing, is preserved in a very unique way that is synthesized with the religious worldview of the community. It is sharing not just simply as liquidation of one's personal assets but also as alleviating the cause of the downtrodden and the poor. Through sharing, the interests of the weakest members of the society are being safeguarded and protected. As the community has been sustained for so many decades, many of the ideas and formulas understood in an abstract manner and informal in style are being transformed into institutional forms that make the choice all the more confusing and hard to understand. When opposition from church is relaxed, there is also laxity among the community members in associating with the outside world. The Ziona's community is shaped by the church either as it tries to defend itself or confront the same. The sect of Ziona is an indigenous Christian sect that is a living witness to the life and struggle of the people in Zomia.

\section{REFERENCES}

[1] Personal interview with the Village Statistician of 
Tlangnuam Baktawng village on 1/12/2016.

[2] Frederick S. Downs, "Christian Conversion Movements among the Hills Tribes of Northeast India in the Nineteenth and Twentieth Centuries," in Religion in South Asia. Religious Conversion in Revival Movements in South Asia in Medieval and Modern Times edited by GA Oddie (Delhi: Manohar publications, 1991), 155- 174.

[3] Frederick S. Downs, “Administrators, Missionaries and a World Turned Upside Down: Christianity as Tribal Response to Change in Northeast India" Indian Church History Review, 99-113.

[4] A term that denotes people belonging to the Chin-Lusei-Kuki clan of Southeast Asia, northeast of India, western part of Myanmar and east of Bangladesh.

[5] Source: Jean Michaud, "Editorial - Zomia and beyond," Journal of Global History 5 (2010), p. 187-214.

[6] Willem van Schendel, "Geographies of knowing, geographies of ignorance: Jumping Scale in Southeast Asia," Environment and Planning D: Society and Space Volume 20 (2012): 647-668.

[7] Michaud, p. 187-214.

[8] Ibidem, p. 187-214.

[9] Schendel, p. $647-668$.

[10] Source: Itty Abraham and Willem van Schendel, "The Making of Illicitness," in Illicit Flows and Criminal Things (Booming and Indianapolis: Indiana University Press, 2005).

[11] Source: James C. Scott, The Art of Not Being Governed. An Anarchist History of Upland Southeast Asia (Delhi: Orient Blackswan, 2010), 9.

[12] Cit. in James C. Scott, The Art of Not Being Governed, p. 286.

[13] Scott, p. 286.

[14] Cite in Scott, p. 313.

[15] Ibidem, p. 319.

[16] Ibidem, p. 321

[17] Source: Ghanshyam Shah, Social Movements in India: A Review of Literature (New Delhi: Sage Publication India Ltd., 1990), p. 92.

[18] Source: Lalsawma, Revival - The Mizo Ways (Aizawl: A Gospel Centenary Souvenir, 1994), p. 184.

[19] Source: V.L. Zaikima, LalpaKohhranThar(New Church of the Lord) (Aizawl: Lengchhawn Press, 2011), p. 18.

[20] Ibidem, p. 19.

[21] Source: Vanlalchhuanga, AnZirtirnate Revised and Enlarged (Their Teachings) (Aizawl: Gosen Press, 1987), 47.

[22] Lalsawma, p. 186.

[23] The so called PPV was a scheme devised to resettle a number of different villages under one cluster to cut off the sources of food supply and shelter as was understood by the Indian Army authorities. The order was issued by B.C. Carriapa, the then Commissioner of the District of Cachar and Mizo Hills under Rule 57 of Defense of India Rules (DIR), 1964; Vijendra Singh Jafa, "Counter Insurgency Warfare: The Use and Abuse of Military Force" in Terror and Containment: Perspectives of India's Internal Security edited by K.P.S. Gill (New Delhi: Gyan Publishing House, 2001), 232; Cited in J.V. Hluna and RiniTochhawng, The Mizo Uprising (Newcastle: Cambridge Scholars Publishing, 2012), 195.

[24] Zaikima, p. 42.

[25] Lalsawma, p. 183

[26] Source: James D. Chancellor, "A Family for the Twenty First Century", in Controversial New Religions edited by James R. Lewis and JesperAagaard Petersen (Oxford: Oxford University Press, 2005), 19-42.

[27] They appealed to the various traditional elements such exotic experiences, dancing, prophesying, drumming, etc. The community is being driven by the leader, who sometimes acts as a seer or a prophet; Source: Vanlalchhuanawma, Mission and Tribal Identity (Delhi: ISPCK, 2010), p. 99.

[28] Source: Chhangte Lal Hminga, The Life and Witness of the Churches in Mizoram (Lunglei: Baptist Literature Service, 1987), p. 199-200; Mangkhosat Kipgen, Christianity and Mizo Culture. The Encounter between Christianity and the Zo Culture (Aizawl: Mizo Theological Conference, 1997), p. 310 .

[29] Source: Saiaithanga, Mizo Kohhran Chanchin (Narratives of Mizo Church) (Aizawl: The Mizo Theological Literature Committee, 1993) $3^{\text {rd }}$ edition, p. 70-71.

[30] Zaikima, p. 55.

[31] Source: James Dokuma, Zoram Kohhran Tualto Chanchinte (Stories of Mizoram Indigenous Churches) (Aizawl: D. Buanga, 1975), p. 43.

[32] Personal interview with Elder Lalthanga at Baktawng on $1^{\text {st }}$ December 2016.

[33] Zaikima, pp. 119-120.

[34] It was a community which was despised by the society, enrolling themselves for proper education involved physical and mental harassment from others that in turn intimidated them to coiled themselves around their own comfort zone; Personal interview with Elder Thanga on 1/12/2016.

[35] There are six major festivals for the community and they are as follows: February 27: Death anniversary of Pu Chana; March 30: Also known as "Chapchar Kut" and it was day on which Khuangtuaha died; June 12: It is commemorate the excommunication from the denominational church; July 21 : It is the Birthday of $\mathrm{Pu}$ Ziona; August 4: It is the death Anniversary of Hualthangi; October 27: It is the Birthday of $\mathrm{Pu}$ Chana

[36] $\mathrm{Pu}$ Chana prophesied on historic events like the termination of chieftainship in the region, India' freedom from the British rule and the return of missionaries to Europe. He also claimed to have seen UFO, some alien and other supernatural objects. 
[37] Comparison can also be made with the Society of Brothers, the Shakers, the Amana Community of the $19^{\text {th }}$ century and the Farm (led by Stephen Gaskin), the Church of Armageddon and Findhorn of recent times.

[38] Source: Joy L.K. Pachuau, Being Mizo. Identity and Belonging in Northeast India (Delhi: Oxford University Press, 2014).

[39] Source: Emile Durkheim, The Elementary Forms of the Religious Life. Translated and with an Introduction (New York: The Free Press, 1954), 44.

[40] Lalsawma, p. 187.

[41] Several members of the cult of People's Temple in Jonestown, Guyan were murdered or committed suicide, Branch Davidian in Waco, Texas and the Order of the Solar Temple in Switzerland also has experienced some form of violent behaviours; Source: John A. Saliba, Perspectives on New Religious Movements (Maryknoll, New York: Orbis Books, 1995), pp. 116-117.

[42] Ibidem, p. 85.

[43] Ibidem, p. 86.

[44] Van lalchhuanawma, Mission and Tribal Identity. A Historical Analysis of the Mizo Synod Mission Board from a Tribal Perspective 1953-1981 (Delhi: ISPCK, 2010), p. 99.

[45] The whole Baktawng, Tlangnuam units have been divided into four classes on the basis of their yearly turnover. There are 12 units having an annual turn-over of less than Rs 180000 , there are 55 units with an annual turnover between Rs 180000-300000 while there are 9 units with a turn-over in the range of Rs 300000-480000 and also there are 9 units with a total annual turn-over above Rs 480000; Source: "Baktawng Wood Carpentry Cluster," NAS Report 2012 for DCS-MSME Research and documented by -EMOTOME, NDBI, National Institute of Design Ahmadabad, Gujarat - 380007, 8.

[46] Vanlalchhuanawma, p. 100.

[47] Zaikima, p. 94. 